\title{
SPACE-TIME VARIABILITY OF VEGETATION BY ORBITAL PLATFORMS IN THE WESTERN AMAZON
}

\author{
VARIABILIDADE ESPAÇO-TEMPORAL DA VEGETAÇÃO ATRAVÉS DE \\ PLATAFORMAS ORBITAIS NA AMAZÔNIA OCIDENTAL
}

\section{Rafael Coll DELGADO'; José Francisco de OLIVEIRA-JÚNIOR ${ }^{1}$; Mariana Campista CHAGAS ${ }^{2}$; Givanildo de GÓIS ${ }^{3}$; Roziane Sobreira dos SANTOS ${ }^{4}$; Paulo Eduardo TEODORO}

1. Professor, Doutor, Instituto de Floresta, Universidade Federal Rural do Rio de Janeiro - UFRRJ, Seropédica, RJ, Brasil; 2. Graduanda do curso de Engenharia Florestal, Instituto de Floresta - UFRRJ, Seropédica, RJ, Brasil; 3. Aluno do Programa de Pós-graduação em Ciências Ambientais e Florestais - PPGCAF, Instituto de Florestas - UFRRJ, Seropédica, RJ, Brasil; 4. Professora, Doutora, Fundação Universidade Federal de Rondônia, Departamento de Matemática e Estatística, Campus Ji-Paraná, RD, Brasil; 5. Aluno do Programa de Pós-Graduação Stricto Sensu em Agronomia - área de concentração: Produção Vegetal da Universidade Estadual de Mato Grosso do Sul, Unidade Universitária de Aquidauana - UEMS/UUA, Aquidauana, MS, Brasil. eduteodoro@ hotmail.com.

\begin{abstract}
Percentage maps (\%) of forest cover derived from the annual product MOD44B were compared with the annual deforestation data from PRODES. PRODES data were used to calibrate the MOD44B (sub-pixel-level representation of surface vegetation cover estimates globally) annual images with the aim of evaluating the annual characterization of the deforestation dynamics and forest regeneration in the municipality of Bujari - Acre, Brazil, from 2000 to 2010. The percentage rates from MODIS were divided into forest cover categories (forested and deforested areas) by means of the Mann-Kendall (MK) non-parametric test used in each category. The results were satisfactory when compared with PRODES. The analysis of MOD44B product in the municipality, during the years 2001, 2004 and 2009, shows that there was an increase of the pixel frequency in the "Extremely High" category, which indicates regeneration of the area in the municipality of Bujari. Validations in situ should be done primarily to the regenerate areas.
\end{abstract}

KEYWORDS: Amazon. Vegetation dynamics. Statistical analysis.

\section{INTRODUCTION}

Deforestation rates in some sites in tropical Africa, Asia and South America remained constant or increased over the past two decades, leading to the need for a more accurate assessment of forest loss (DEFRIES et al. 2002; LAMB et al., 2005). The deforestation spatial distribution in the Amazon can be associated with two interrelated factors: (i) due to the roads opening influence and appearing of development centers in the occupation process encouraged by the federal government in recent decades (ALVES et al., 1999; ALVES, 2002), (ii) land use concentration processes or expansion of new areas of deforestation associated with intensification/land abandonment e aumento de incêndios florestais e queimadas na região (ALVES et al., 2003; ALVES, 2007; CAÚLA et al., 2015).

In addition, the concentrate deforestation in some areas that are influenced by pastures and crops leads to the formation of the few remaining forests and prevent the growth of secondary vegetation (ALVES et al., 2003).

Secondary vegetation, formed by natural regeneration of deforested and abandoned areas are important in carbon sequestration (C) (NOBRE; NOBRE, 2002), assists in the creation of biodiversity corridors (BARLOW et al., 2006; STOUFFER et al., 2006), cycling and fixing of nutrients to the soil (SZOTT et al., 1999) and maintaining of the hydrological cycle in the region, integrating the coverage and change process of use of the Amazonian soil (FEARNSIDE, 2005).

In the Amazon region, the use of data obtained from orbital platforms enables high reliability studies on spatial and temporal scales in this region, regularly covering various regions of the planet, being these adjusted continuously (FREITAS et al., 2012; VILANOVA et al., 2013).

One of the sensors most widely used in large-scale studies is MODIS (Moderate Resolution Imaging Spectroradiometer). Its data are available since 2000, thus constituting one of the most reliable sources regarding to large-scale studies or even globally (ZHANG et al., 2009). MODIS land cover system products provide various types of input data for the monitoring of deforestation as, for example, the product MOD44B. VCF product is a global representation of the Earth's surface, and has three gradations of soil cover components: percentage of tree cover, percentage of nonvegetated area and percentage of bare area (HANSEN et. al., 2005; TOWNSHEND et al., 2001). 
This study aimed to evaluate the annual characterization of the dynamics of deforestation and forest regeneration existent in the municipality of Bujari - Acre, Brazil from 2000 to 2010, based on high-resolution data of the product MOD44B and, finally, compare the PRODES data (Deforestation Monitoring Project Satellite in the Legal Amazon) /INPE (National Institute of Spatial Research).

\section{MATERIAL AND METHODS}
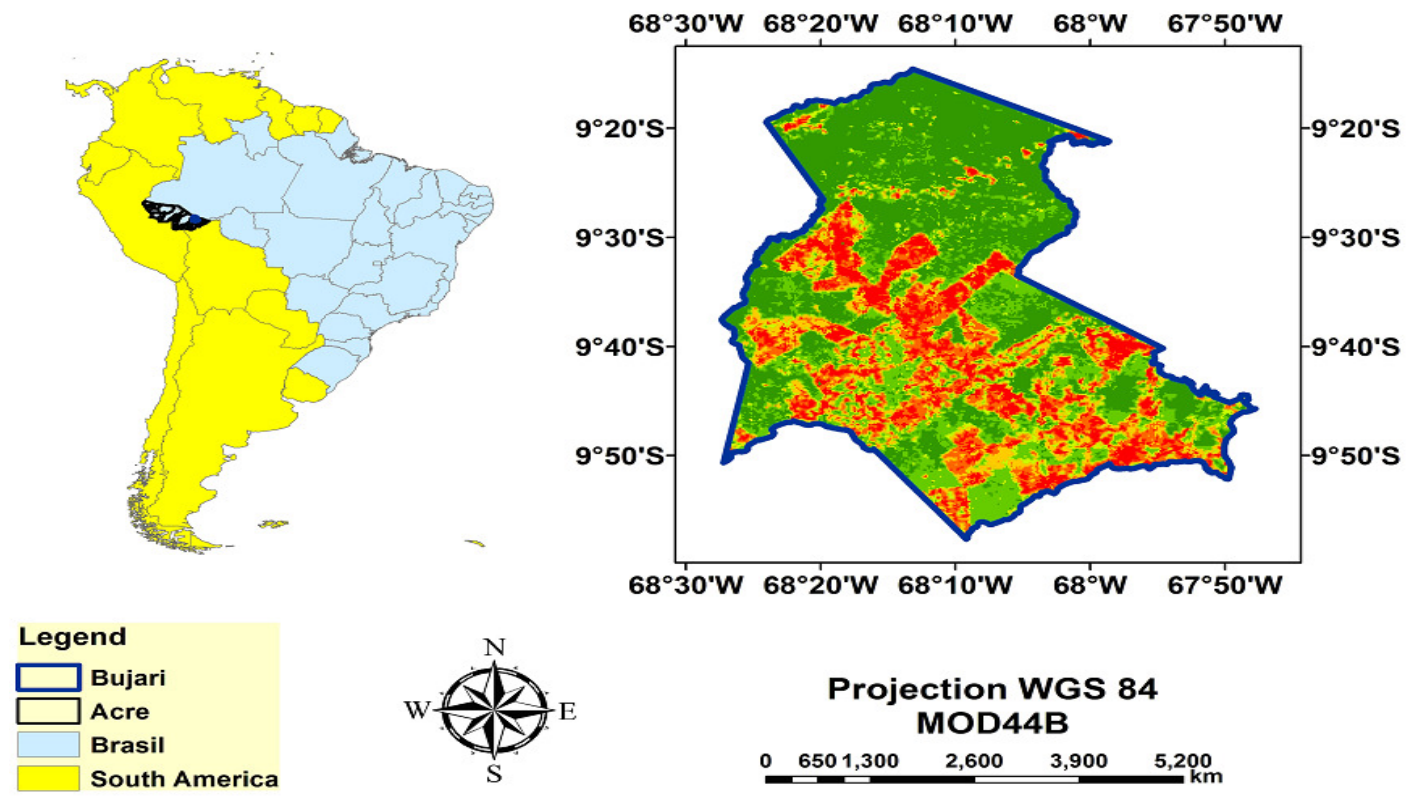

Figure 1. Geographical location of the study area and to the right MOD44B image for the year 2009.

\section{Data processing}

In this study were used 11 images annual of MOD44B product, coming from of sensor MODIS on board the orbital platform TERRA, with annual composition and spatial resolution of $250 \mathrm{~m}$ from 2000 to 2010. The images were acquired on April 22, 2013 coming from the NASA-EOSDIS (National Aeronautics and Space Administration Earth Observing System Data and Information System), at the following website: www.reverb.echo.nasa.gov.

MODIS data were used for carrying out of pixels reading in PRODES polygons vegetation cover density, for the monitoring of deforestation dynamics and regeneration over the period. This monitoring was done in all the polygons mapped by PRODES in the municipality of Bujari, AC. The data were processed using the ArcGIS 10.1 software.

MODIS's raster images were transformed into points to facilitate the counting of the categories in percentage scale vegetation coverage found in

\section{Characterization and location of the study area}

Bujari, in the state of Acre, is situated in $09^{\circ} 49^{\prime} 50^{\prime \prime} \mathrm{S}$ and $67^{\circ} 57^{\prime} 08^{\prime \prime} \mathrm{W}$ (Figure 1). It has an area of $3,035.869 \mathrm{Km}^{2}$ with 8,471 inhabitants and a population density of 2.79 inhabitants / $\mathrm{km}^{2}$ (IBGE, 2014). The climate is "Aw," according to Köppen's climatic classification. The state of Acre is divided climatically into two main types of climate: humid tropical ("Af") and monsoon tropical ("Am") (Duarte, 2005).

each polygon and posterior statistical analysis. For this, we used the module Arctoolbox - Convertion Tools - From Raster - Raster to Point (Figure 2).

PRODES polygons were classified into three groups: deforestation relating to the year image, forest and deforestation. It were selected the data concerning the classification found in PRODES attribute table, and with the tool Arctoollbox analist tools - extract - clip were developed maps with points of each group. For the classification of forest group, we selected all polygons referring to subsequent years from the year of the image. Deforestation group is related to polygons that were later added to PRODES in 2010. Este procedure was repeated for all MODIS images of the study period. The data from attribute table in the maps of each group in MODIS images from 2000 to 2010 were exported from ArcGis 10.1. 


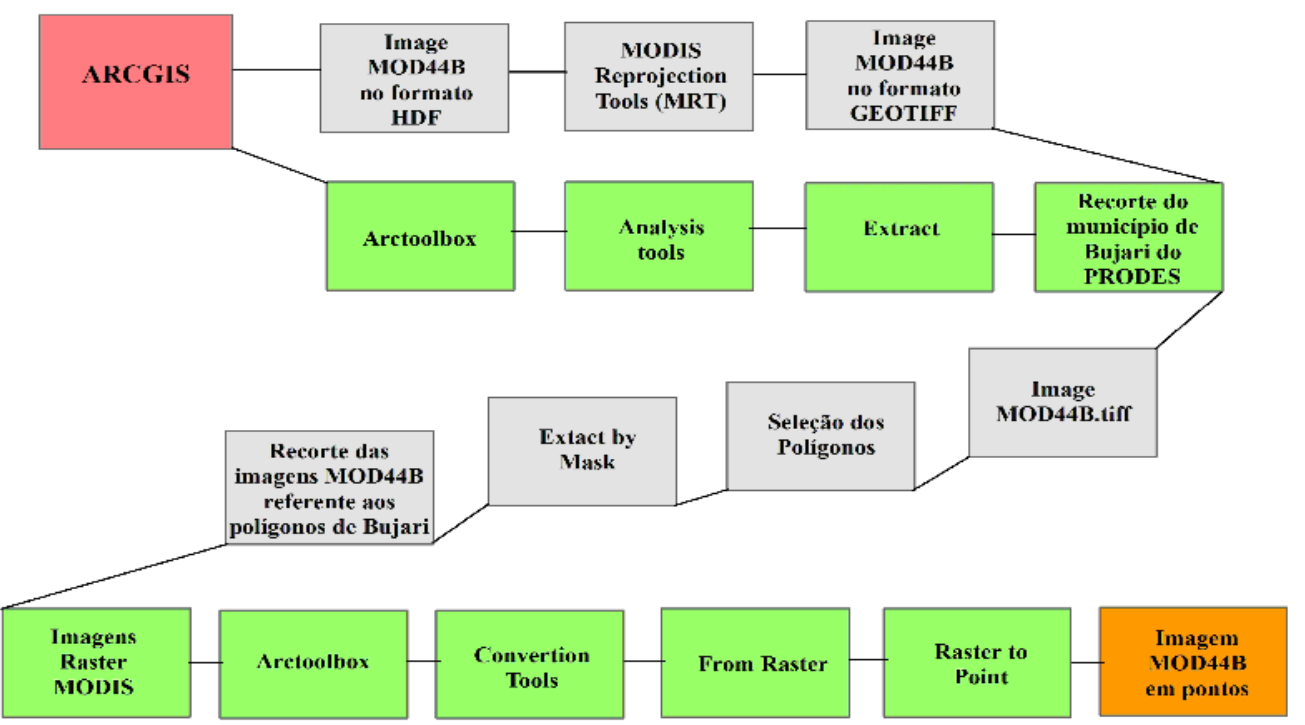

Figure 2. Flowchart related to the processing of data in ArcGIS 10.1 MOD44B software product.

According to the methodology proposed by Vilanova et al. (2013), the percentage of forest cover have been categorized: Extremely Low (0\% to $5 \%$ ), Very Low (5\% to $17 \%$ ), Moderately Low (17\% to $35 \%$ ), Moderately High (35\% to $54 \%$ ), Very High (54\% to $71 \%)$ and Extremely High (71\% to $89 \%)$.

\section{Statistical analysis of the data}

In order to assess change over the years and each category to the forested and deforested areas we used the Mann-Kendall non-parametric test (MK) (MANN, 1945; KENDALL, 1975). The test identifies the presence of monotonous trend without making assumptions about the properties of the data distribution. In order to perform the test a significance level $(\alpha)$ at $5 \%$ will be adopted. The test considers the null hypothesis $\left(\mathrm{H}_{0}\right)$ that there is no trend in the category under consideration, against the alternative hypothesis that there is a trend of increase or decrease in the said category. It used the $\mathrm{R}$ software version 3.2.0 ( $\mathrm{R}$ Development Core Team, 2014).

MK test considers that, in case of stability of a time series, the succession of values occurs independently and the probability distribution should always remain the same (the series should be random).

Based on the $\mathrm{Z}$ statistic analysis a decision is taken to accept or reject $\mathrm{H}_{0}$, that is, is it possible to confirm the hypothesis of data stability or reject it in favor of the alternative hypothesis (existence of trend in the data). The $\mathrm{Z}$ statistic signal indicates if the trend is increasing $(Z>0)$ or decreasing $(Z<0)$. In a bilateral test for trend, $\mathrm{H} 0$ should be rejected if the p-value found in the test statistic is less than or equal to the significance level adopted.

\section{RESULTS AND DISCUSSION}

From the division of forest coverage ratios in categories (Table 1)were performed some analysis related to land use change and driving forces operating in the deforestation process in the municipality of Bujari, AC. It was evaluated the time sequence for the years 2001, 2004, 2007 and 2010 of the MOD44B product occurred in Bujari, so as to locate the conversions of forest, deforestation and forest regeneration from the coverage ratios during this period (Figure 3 ). The category with the highest percentage rate of forest cover was Extremely High $(65.1 \%, 2001)$ and in the year 2010 $(35.0 \%)$, a reduction of $30 \%$. This result is corroborated by the MK non-parametric test, which showed a significant annual decrease of 2.36 in this category.

The years 2001, 2004 and 2009 in the total analysis of the MOD44B product in the municipality, there was an increase in the pixels frequency of the Extremely High category, which indicates regeneration of the municipal area. Comparing the years 2008 and 2009, the frequencies of the Extremely High categories were $36.6 \%$ and $47.9 \%$ respectively (Table 1 ). 
Table 1. Pixels frequency in percentage (\%) of the forest cover categories obtained from MODIS product for the municipality of Bujari, AC, in the period $2000-2010$.

\begin{tabular}{lccccccccccc}
\hline \multicolumn{1}{c}{ Categories } & $\mathbf{2 0 0 0}$ & $\mathbf{2 0 0 1}$ & $\mathbf{2 0 0 2}$ & $\mathbf{2 0 0 3}$ & $\mathbf{2 0 0 4}$ & $\mathbf{2 0 0 5}$ & $\mathbf{2 0 0 6}$ & $\mathbf{2 0 0 7}$ & $\mathbf{2 0 0 8}$ & $\mathbf{2 0 0 9}$ & $\mathbf{2 0 1 0}$ \\
\hline Extremely Low & 0.26 & 0.17 & 0.01 & 0.24 & 0.02 & 0.02 & 0.02 & 0.02 & 0.01 & 0.00 & 0.04 \\
Very Low & 13.3 & 10.5 & 12.5 & 13.7 & 14.3 & 10.4 & 12.1 & 12.8 & 10.8 & 1.8 & 6.6 \\
Moderately Low & 10.2 & 11.7 & 10.6 & 11.3 & 12.4 & 17.3 & 16.8 & 15.8 & 18.5 & 22.0 & 20.3 \\
Moderately High & 6.4 & 8.9 & 7.2 & 9.9 & 6.4 & 9.2 & 9.3 & 13.3 & 14.0 & 10.5 & 13.1 \\
Very High & 16.0 & 3.5 & 12.8 & 17.3 & 10.3 & 11.5 & 18.4 & 15.6 & 20.0 & 17.9 & 24.8 \\
Extremely High & 53.8 & 65.1 & 57.0 & 47.5 & 56.7 & 51.5 & 43.3 & 42.7 & 36.6 & 47.9 & 35.0 \\
\hline
\end{tabular}
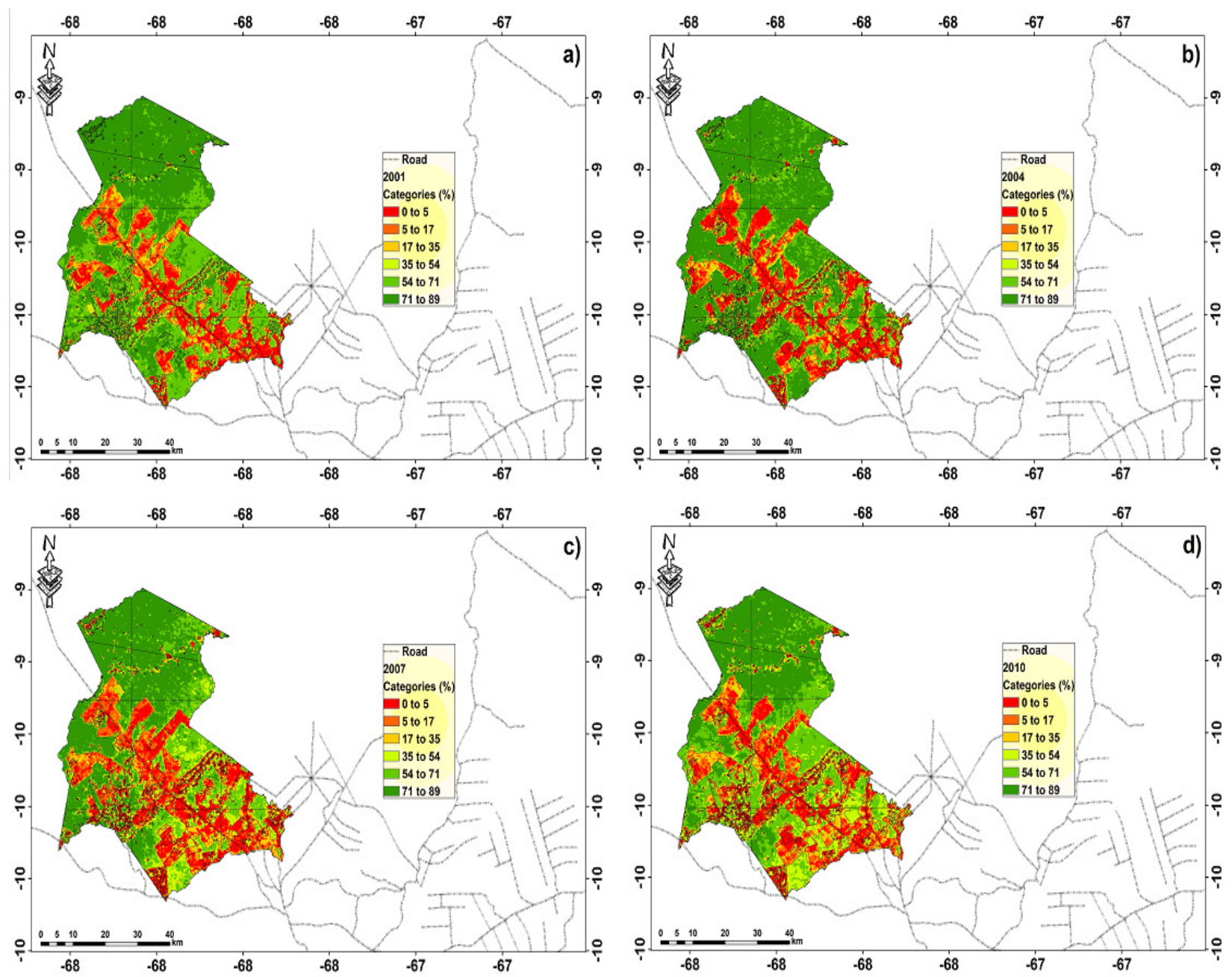

Figure 3. Percentage maps (\%) of forest cover based on MOD44B product categories from 2001 (a) 2004 (b) 2007 (c) to 2010 (d) of the municipality of Bujari, AC.

This behavior of the spatial distribution of forest cover categories in the years 2007 to 2009 can be explained according to the PRODES data, where it was calculated that the years 2007 and 2008 had an lowest deforestation increment in the period, with only $9 \mathrm{~km}^{2}$ (Figure 4). This possible regeneration of the area can be explained by the reduction of largescale disturbances, since the regeneration dynamics is strongly influenced by endogenous factors (vegetation structure and interaction among species) 
(AUGSPURGER, 1984). In addition, the less intensive use of land in the first years after deforestation and the best state of the seed bank (UHL and CLARK, 1983) may explain the higher proportion of regenerated area in 2007 and 2008 compared to previous years in the studied region.

These results found for the years 2007 and 2008 are in agreement with the conclusions found by Caldato et al. (2009), who recommend, because of large seasonality in the production and seed accumulation in a period exceeding one year in tropical forests. These authors also emphasize that the study in not changed wild areas is essential to have an understanding of these complex structures, placing greater emphasis on research focusing on the environmental behavior of the beings in the ecosystem.

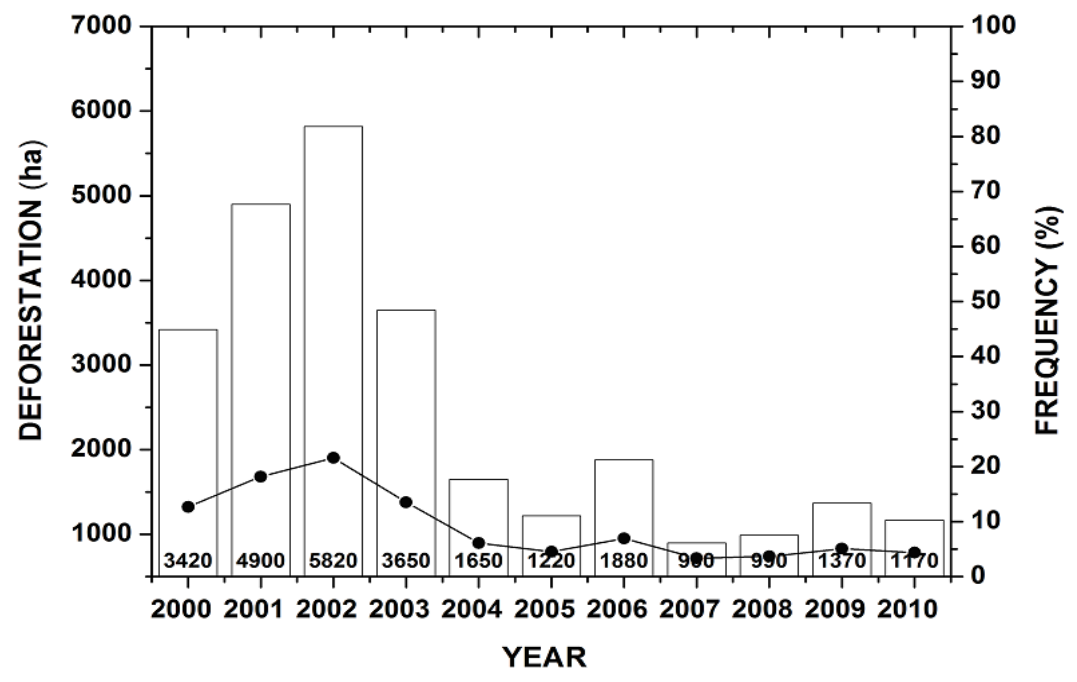

Figure 4. Increase DEFORESTATION and frequency (\%) based on PRODES- INPE system in hectare (ha). Source: Bank of PRODES data.

In the categories namely Very High and Moderately High there is a significant increase of $21.3 \%$ and $4.2 \%$ for the same period. However, only in category Very High this increase is significant at $5 \%$ level (Table 2). With the reduction of percentage rates in the high categories, followed by an increase in low percentage rates, it is verified the replacement of percentage rates in the high categories over 10 years and consequently decrease of forest cover density in Bujari.

Table 2. Mann-Kendall test applied to the categories of forest and deforestation in the municipality of Bujari, $\mathrm{AC}$, in the period $2000-2010$.

\begin{tabular}{lcccc}
\hline \multirow{2}{*}{ Categories } & \multicolumn{2}{c}{ Deforestation } & \multicolumn{2}{c}{ Forest } \\
\cline { 2 - 5 } & Inclination & p-value & Inclination & p-value \\
\hline Very Low & 0.00 & 0.63 & 0.00 & 1.00 \\
Moderately Low & 1.82 & $0.00^{*}$ & 0.17 & $0.02^{*}$ \\
Moderately High & 3.12 & $0.01^{*}$ & 0.48 & 0.06 \\
Very High & 0.91 & 0.31 & 1.97 & $0.04^{*}$ \\
Extremely High & -6.32 & $0.00^{*}$ & -2.36 & $0.01^{*}$ \\
\hline
\end{tabular}

According to the data obtained from PRODES (Figure 5), the deforestation in Bujari gradually increased in the categories Moderately Low and High, especially in 2005, compared to other categories over the period, by the MK test this was of 1.82 and 3.12 , respectively (Table 2). In comparison with the distribution of the pixels frequency in each forest cover category does not confirm the results on the reduction of forest cover category Extremely High annual.

The reduction is due to the land use process in the state of Acre that occurred in the 1980's, from public colonization policies with highway construction and land acquisition incentives for business groups (domestic and foreign) (MARGULIS, 2003; VILANOVA et al, 2013). 
According to Fearnside (2005), abandoned pasture areas give rise to secondary vegetation with slower regeneration and lower biomass accumulation, compared to the secondary vegetation of itinerant agriculture. Thus, the deforestation process occurs faster than the forest resilience capacity in the region.

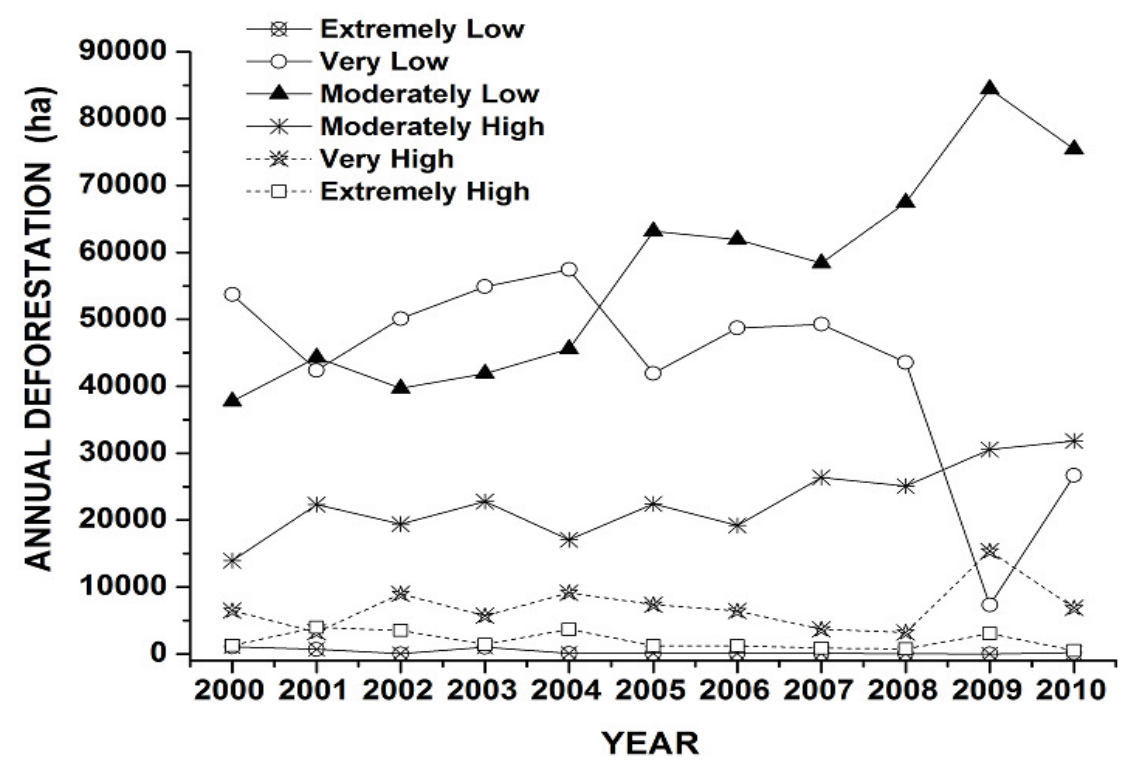

Figure 5. Distribution of annual deforestation in hectare (ha) according to PRODES system. Source: Bank of PRODES data.

\section{CONCLUSIONS}

Spatial and temporal analysis of the pixels distribution divided into categories of forest cover percentage in the images can explain the deforestation and regeneration dynamics of the study area, based on the raw data calculated by the PRODES system.

The reduction of the size of deforested increments from the PRODES in the region, when compared with images from the MODIS product, shows possible forest regeneration in the municipality of Bujari, AC, over the period. The raw data from the PRODES system does not infer on regenerated areas which may overestimate the total deforestation values.
In the statistical analyzes, some categories showed no significant variability among the years evaluated. However, the high pixels frequency with the spatial analysis, these categories can reveal possible relationship with the PRODES data.

It is noteworthy that the frequency analysis should be done together with the visual classification of maps. Validations in situ, especially for the regenerated areas should be performed.

\section{ACKNOWLEDGEMENTS}

To Centro de Previsão do Tempo e Estudos Climáticos of Instituto Nacional de Pesquisas Espaciais (CPTEC-INPE) for providing data from the PRODES and to NASA by the MOD44B data.

RESUMO: Mapas percentuais (\%) de cobertura florestal provenientes do produto anual MOD44B foram comparados com dados anuais de desflorestamento anual PRODES. Os dados do PRODES foram utilizados para calibrar as imagens anuais MOD44B (representação sub-pixel-nível de estimativas de cobertura de vegetação de superfície a nível mundial) com o objetivo de avaliar a caracterização anual da dinâmica de desmatamento e regeneração de florestas no município de Bujari - Acre, Brasil entre 2000 a 2010. Os índices percentuais do MODIS foram divididos em categorias de cobertura florestal (áreas desflorestadas e florestadas) por meio do teste não-paramétrico Mann-Kendall (MK) em cada categoria. Os resultados foram satisfatórios quando comparados com PRODES. Observa-se um aumento da frequência de pixels da categoria Extremamente Alta nos de 2001, 2004 e 2009 na análise total do produto MOD44B no município, o que indica a regeneração da área do município de Bujari. Devem ser realizadas validações in situ principalmente para áreas regeneradas.

PALAVRAS-CHAVE: Amazônia. Dinâmica da vegetação. Análise estatística. 


\section{REFERENCES}

ALVES, D. S. Science and technology and sustainable development in Brazilian Amazon. In: Stability of tropical rainforest margins. Berlin: Springer, 2007. p. 491-510. http://dx.doi.org/10.1007/978-3-540-30290$2 \_23$

ALVES, D. S. Space-time dynamics of deforestation in Brazilian Amazon. International Journal of Remote Sensing, London, v. 23, n.14, p.2903-2908. 2002. http://dx.doi.org/10.1080/01431160110096791

ALVES, D. S.; ESCADA, M. I. S.; PEREIRA, J. L. G.; LINHARES, C. A. Land use intensification and abandonment in Rondônia, Brazilian Amazonia. International Journal of Remote Sensing, London, v. 24, n. 4, p. 899-903, 2003. http://dx.doi.org/10.1080/0143116021000015807

ALVES, D.S.; PEREIRA, J.L.G.; SOUSA, C.L.; SOARES, J.V.; YAMAGUCHI, F. Characterizing landscape changes in central Rondônia using Landsat TM imagery. International Journal of Remote Sensing, London, v.20, n.14, p.2877-2882, 1999. http://dx.doi.org/10.1080/014311699211859

AUGSPURGER, C. K. 1984. Seedling survival of tropical tree species: interactions of dispersal distance, light gaps and pathogens. Ecology, New York, v. 65, n. 6, p. 1705-1712, 1984. http://dx.doi.org/10.2307/1937766

BARLOW, J.; PERES, C. A.; HENRIQUES, L. M. P.; STOUFFER, P. C.; WUNDERLE, J. M. The responses of understorey birds to forest fragmentation, logging and wildfires: An Amazonian synthesis. Biological Conservation, Boston, v. 128, n. 2, p. 182-192, 2006. http://dx.doi.org/10.1016/j.biocon.2005.09.028

CALDATO, S. L.; FLOSS, P. A.; DA CROCE, D. M.; LONGHI, S. J. Estudo da regeneração natural, banco de sementes e chuva de sementes na reserva genética florestal de Caçador, SC. Ciência Florestal, Santa Maria, v. 6, n. 1, p. 27-38, 2009.

CAÚLA, R. H.; OLIVEIRA-JÚNIOR, J. F.; LYRA, G. B.; DELGADO, R. C.; HEILBRON FILHO, P.F.L. Overview of fire foci causes and locations in Brazil based on meteorological satellite data from 1998 to 2011. Environmental Earth Sciences (Print), v. 74, n. 2, p. 1497-1508, 2015. http: //dx.doi.org/10.1007/s12665015-4142-Z

DEFRIES, R.; HOUGHTON, R. A.; HANSEN, M. C.; FIELD, D.; SKOLE, L.; TOWNSHEND, J. Carbon emissions from tropical deforestation and regrowth based on satellite observations for the 1980s and 90s. Proceedings of the National Academy of Sciences, Washington, v. 99, n. 22, p. 14256-14261, 2002.

DUARTE, A. F. Variabilidade e tendência das chuvas em Rio Branco, Acre, Brasil. Revista Brasileira de Meteorologia, São José dos Campos, v. 20, n. 1, p. 37-42, 2005.

FEARNSIDE, P. M. Deforestation in Brazilian Amazonia: History, rates, and consequences. Conservation Biology, Malden, v. 19, n. 3, p. 680-688, 2005. http://dx.doi.org/10.1111/j.1523-1739.2005.00697.x

FREITAS, D. M.; DELGADO, R. C.; RODRIGUES, R. A.; SOUZA, L. P. Variabilidade espaço-temporal na mudança da paisagem no município de Acrelândia, AC. Enciclopédia Biosfera, Goiânia, v. 8, p. 935-946, 2012.

HANSEN, M. C.; DEFRIES, R. S.; TOWNSHEND, J. R. G.; CARROLL, M. Estimation of tree cover using MODIS data at global continental and regional/local scales. International Journal of Remote Sensing, London, v. 26, n. 19, p. 4359-4380, 2005. http://dx.doi.org/10.1080/01431160500113435

Instituto Brasileiro de Geografia e Estatística - IBGE. $<2014$. http://www.cidades.ibge.gov.br/xtras/perfil.php?lang=\&codmun=120013\&search=acrelbujari>. Acesso em: 04 fev. 2014. 
KENDALL, M. G. Rank correlation methods, London: Charles Griffin. 1975.

LAMB, D.; ERSKINE, P. D.; PARROTTA, J. A. Restoration of Degraded Tropical Forest Landscapes.

Science, Washington, v. 310, n. 5754, p. 1628 - 1632, 2005. http://dx.doi.org/10.1126/science.1111773

MANN, H. B. Non-parametric test against trend. Econometrica, Malden, v. 13, p. 245-259, 1945.

http://dx.doi.org/10.2307/1907187

MARGULIS, S. Causas do desmatamento na Amazônia Brasileira. 1ª ed. Brasília: Banco Mundial, 2003.

NOBRE, C. A.; NOBRE, A. D. O balanço de carbono da Amazônia brasileira. Estudos Avançados, São Paulo, v. 16, n. 45, p. 81-90, 2002. http://dx.doi.org/10.1590/S0103-40142002000200006

R DEVELOPMENT CORE TEAM. R: a language and environment for statistical computing. Vienna: R Foundation for Statistical Computing, 2014. Recuperado de http://www.R-project.org.

STOUFFER, P. C.; BIERREGAARD, R. O.; STRONG, C.; LOVEJOY, T. E. Long - term landscape change and bird abundance in Amazonian rainforest fragments. Conservation Biology, Malden, v. 20, n. 4, p. $1212-$ 1223, 2006. http://dx.doi.org/10.1111/j.1523-1739.2006.00427.x

SZOTT, L. T.; PALM, C. A.; BURESH R. J. Ecosystem fertility and fallow function in the humid and subhumid tropics. Agroforestry Systems, Amsterdã, v. 47, n. 1-3, p. 163-196, 1999.

TOWNSHEND, J. R. G.; CARROLL, M. C.; DIMICELI, R.; SOHLBERG, M.; HANSEN, R. F. Vegetation Continuous Fields MOD44B, 2001 Percent Tree Cover, Collection 5, University of Maryland, College Park, Maryland, 2001.<http://www.landcover.org/library/guide/VCF_C5_UserGuide_Dec2011.pdf> Acesso em: 10 fev. 2013.

UHL, C.; CLARK, K. Seed ecology of selected Amazon Basin successional species. Botanical Gazette, London, v. 144, 1983.

VILANOVA, R. S.; ANDRADE, M. S. S.; DELGADO, R. C.; OLIVEIRA-JÚNIOR, J. F.; SANTOS, R. D. B. Cobertura florestal da Tectona grandis L. f. Baseado nos produtos MOD44B e 3B43 em Plácido de Castro, AC. Enciclopédia Biosfera, Goiânia, v. 9, n. 17, p. 681-695, 2013.

ZHANG, Y.; XU, M.; CHEN, H.; ADAMS, J. Global pattern of NPP to GPP ratio derived from MODIS data: effects of ecosystem type, geographical location and climate. Global Ecology and Biogeography, Malden, v. 18, n. 3, p. 280-290, 2009. http://dx.doi.org/10.1111/j.1466-8238.2008.00442.x 